\title{
Local people's knowledge on the adverse impacts and their attitudes towards growing Eucalyptus woodlot in Gudo Beret Kebele, Basona Worena district, Ethiopia
}

\author{
Solomon Ayele Tadesse ${ }^{*^{*}}$ and Solomon Mulu Tafere ${ }^{2}$
}

\begin{abstract}
Introduction: Growing Eucalyptus at a farm level in the form of woodlot has become popular among rural households in Ethiopia. For example, rural households mainly establish Eucalyptus woodlot as a component of livelihood improvement and diversification to meet household wood demand and generating cash income. However, there is lack of information on the growth parmeters of Eucalyptus woodlot and the factors influencing the household decision on their establishment at the individual farmland level. The objective of this study was to examine local people's knowledge on the adverse impacts and their attitudes towards growing Eucalyptus woodlot in Gudo Beret Kebele. We hypothesized that local people's knowledge on the adverse impacts and their attitudes towards growing Eucalyptus woodlot in Gudo Beret Kebele is affected by socioeconomic and cognitive variables.
\end{abstract}

Methods: A structured questionnaire comprising closed- and open-ended questions was developed and administered to a total of $n=94$ households to collect information on local people's knowledge on the adverse impacts and their attitudes towards growing Eucalyptus woodlot. The households were randomly selected through a lottery system based on their house identification numbers. Descriptive statistics, binary logit, and multiple linear regression were used to analyze and interpret the data.

Results: The results revealed that about $92 \%$ of the respondents noted that growing Eucalyptus woodlot had positive impacts on the socioeconomic situation of the community considering that it contributes to economic benefits through the sale of wood products, such as poles, construction materials, and fuelwood. However, only $8 \%$ of the respondents noted that the negative impacts of Eucalyptus woodlot were attributed to the decline in crop and forage production due to its allelopatic effect, and the reduction in ground water availability. Majority of the respondents (about 68\%) preferred to grow Eucalyptus woodlot in Gudo Beret Kebele. Thus, most of the respondents (about 69\%) had strongly agreed to have a positive attitude towards growing Eucalyptus woodlot. On the other hand, the binary logit regression model explained about $70.6 \%$ of the variance of local people's knowledge on the adverse impacts of Eucalyptus woodlot. Overall, the multiple linear regression model revealed that socioeconomic and cognitive variables had significant effect on local people's attitudes towards growing Eucalyptus woodlot (39.5\% variance explained).

Conclusions: We recommended that foresters, natural resource experts and managers, environmentalists, land use planners, and policy-makers should take the right and careful decision by assessing the overall socioeconomic and ecological aspects of Eucalyptus woodlot based on the interests of various stakeholders including local communities.

Keywords: Adverse impacts, Binary logit regression, Cognitive variables, Eucalyptus, Fuelwood, Local communities, Multiple linear regression, Rural households, Socioeconomic variables, Woodlot

\footnotetext{
* Correspondence: solomon.ayele1972@gmail.com

'Department of Natural Resources Management, College of Agriculture and

Natural Resource Sciences, Debre Berhan University, P.O. Box 445, Debre

Berhan, Ethiopia

Full list of author information is available at the end of the article
}

(c) The Author(s). 2017 Open Access This article is distributed under the terms of the Creative Commons Attribution 4.0 International License (http://creativecommons.org/licenses/by/4.0/), which permits unrestricted use, distribution, and reproduction in any medium, provided you give appropriate credit to the original author(s) and the source, provide a link to the Creative Commons license, and indicate if changes were made. \\ Springer Open}




\section{Introduction}

Ethiopia has lost majority of its forest resources especially during the twentieth century (EFAP 1994). The forest depletion, together with the sharply increasing human population, has resulted in a severe shortage of wood products especially for fuelwood and construction materials (Ayele 2008; Liang et al. 2016). This also has stemmed from the very strong dependence on wood products by the majority of the society as there is poor infrastructural development in the country (Hailu 2002; Hailu et al. 2003). One of the measures taken by the government to minimize the problem of scarcity of wood products was to introduce fast-growing exotic tree species (e.g., Eucalyptus camaldulensis and Eucalyptus globulus) and establish fuelwood projects near urban and peri-urban areas (Ayele 2008; Liang et al. 2016). It is within this scheme that Eucalyptus species were introduced into Ethiopia by the government of Menelik II and were distributed to the farmers for planting at farm boundaries and around homesteads (Hailu 2002; Hailu et al. 2003; Ayele 2008). In Australia (i.e., place of origin for the two Eucalyptus species), Eucalyptus camaldulensis and Eucalyptus globulus are commercially grown mainly for timber production and raw material for pulp and paper factories (Jacobs 1955; Jacobs 1961; Hall et al. 1970). However, in Ethiopia, rural households establish Eucalyptus woodlot of these two species as a component of livelihood improvement and diversification to meet household wood demand and generating cash income through the sale of wood products, such as poles, construction materials, and fuelwood (Ayele 2008; Bekele 2015).

In northern Ethiopia, Eucalyptus is the most commonly grown tree species in a community and private woodlots. Eucalyptus grows well and fast even on poor soils compared to most indigenous tree species (Hailu 2002; Hailu et al. 2003). Smallholders show a clear preference for Eucalyptus poles, which are useful for farm implements and construct houses and fences in the highlands of Ethiopia (Ayele 2008). In addition, the sale of Eucalyptus poles and other wood products has the potential to raise farm incomes, reduce poverty, increase food security, and diversify farming system in many areas of Amhara National Regional State (Hailu 2002; Ayele 2008; Kebebew and Ayele 2010). In addition to this, Eucalyptus plantations play a great role as a main source of fuelwood to both urban and rural inhabitants (Hailu et al. 2003; Liang et al. 2016).

According to previous studies (e.g., EFAP 1994; Hailu 2002; Hailu et al. 2003; Ayele 2008; Zewdie 2008; Liang et al. 2016), there was no environmental impact assessment which was done before the introduction of the genus Eucalyptus in Ethiopia. Although planting Eucalyptus was started in Ethiopia in the early part of the twentieth century, farmers and forestry personnel told that private farm tree planting in Ethiopia is relatively a recent phenomenon that gradually expanded as part of the afforestation campaigns of the 1970s and the 1980s (EFAP 1994; Ayele 2008; Negasa et al. 2016). Presently, private farm trees, nearly all Eucalyptus woodlots, are planted mostly on hilly patches, parts of farmlands that are not suitable for growing food crops, and around homesteads (Ayele 2008; Gemechu 2010; Negasa et al. 2016; Negasa et al. 2017a). However, common problems facing with Eucalyptus management in Ethiopia include termite and frost damages, fire, illegal tree cutting, and animal trampling of seedlings, mainly at establishment stages (EFAP 1994; Hailu 2002; Hailu et al. 2003; Ayele 2008).

The ongoing expansion of Eucalyptus plantations by farmers in Ethiopia (e.g., Fisseha et al. 2011; Kindu et al. 2013; Yeshaneh et al. 2013; Desalegn et al. 2014; Tesfaye et al. 2014) have been the focus of two major debates on the environmental impact and the economic role of the species. The former debate is related to soil acidification (Liang et al. 2016), nutrient depletion (Negasa et al. 2017a), allelopathic effect (Bowen and Nambiar 1984; Basu and Kandasamy 1997; Hailu et al. 2003), and excessive water utilization by the species especially when grown on previously cultivated farmlands (Saint-André et al. 2008; Hailu et al. 2003; Liang et al. 2016; Negasa et al. 2017b). However, the later debate focuses on the importance of the species because of its fast growth, high biomass production and coppicing ability, browsing, and diseases resistance (Kindu et al. 2006; Hailu 2002; Zewdie 2008; Negasa et al. 2016). In Ethiopia, where there are huge gaps between demand and supply of wood products as a result of the accelerating deforestation (Ayele 2008; Bekele 2015), the use of fast-growing species which produce a large amount of biomass like Eucalyptus is inevitable (Kindu et al. 2006). Despite the potential importance of Eucalyptus, the associated environmental concerns, such as the impoverishment of soil fertility (Bowen and Nambiar 1984; Hailu et al. 2003; Negasa et al. 2017a), depletion of groundwater (Negasa et al. 2017b), and soil acidification (Liang et al. 2016), are yet to be quantified and evaluated from the sustainable utilization standpoint based on Ethiopian site-specific conditions (Hailu 2002; Hailu et al. 2003). This implies that the demand for further investigation regarding the adverse environmental impacts of Eucalyptus is very high.

To address the aforementioned gap, the aim of this study was to examine local people's knowledge on the adverse impacts and their attitudes towards growing Eucalyptus woodlot in Gudo Beret Kebele, Basona Worena district, Ethiopia. Accordingly, we hypothesized that local people's knowledge on the adverse impacts and their attitudes towards growing Eucalyptus woodlot in Gudo Beret Kebele is affected by socioeconomic and 
cognitive variables (e.g., Hills 1995; Knight et al. 2004; Tadesse and Kotler 2016; Tadesse and Teketay 2017).

\section{Methods}

\section{Study area}

The study was conducted in Gudo Beret Kebele (Kebele is the smallest administrative unit in Ethiopia), Basona Worena district, Ethiopia. Gudo Beret Kebele is located on $10^{\circ} 41^{\prime} 50^{\prime \prime}$ ' north and $39^{\circ} 47^{\prime} 03^{\prime \prime}$ ' east at a distance of $162 \mathrm{~km}$ northeast of Addis Ababa and $32 \mathrm{~km}$ in the same direction from Debre Berhan town (Fig. 1). Elevation ranges from 2828 to $3700 \mathrm{~m}$ above sea level (Ayele 2008). The total area of Gudo Beret Kebele is about 7054 ha among which 1418 ha are plantation forests (i.e., tree species like Eucalyptus globulus, Eucalyptus camaldulensis, and Juniperus procera), 923 ha grazing land, and the remaining 4713 ha are allocated for cultivated land. The total population size of Gudo Beret Kebele is estimated to be about 4550 inhabitants, and the population density is estimated to be 90.03 persons $/ \mathrm{km}^{2}$. The total number of households in Gudo Beret Kebele is 1062. Majority of the local people's income is derived from mixed farming (i.e., crop production and livestock rearing) (Personal communication with Basona Worena district Agriculture and Rural Development Office, December 20, 2016).

The study site had a mean annual temperature and rainfall of about $15.5{ }^{\circ} \mathrm{C}$ and $1200 \mathrm{~mm}$, respectively (Teketay and Bekele 1995). According to previous studies, Eucalyptus globulus and Eucalyptus camaldulensis can grow and perform best in cool and humid highlands of agro-ecological zone (i.e., locally known as "Dega") (Hailu 2002; Hailu et al. 2003; Ayele 2008), suggesting that this agro-ecological zone is similar to the present study site. Thus, it is believed that Gudo Beret Kebele is ecologically suitable for the growth of both Eucalyptus species. In Gudo Beret Kebele, rural households mainly grow Eucalyptus woodlot for fuelwood, construction materials, and poles (Kebebew and Ayele 2010; Bekele 2015; Liang et al. 2016).

Based on the information obtained from the respondents during the questionnaire survey, growing Eucalyptus globulus and Eucalyptus camaldulensis around farm boundaries reduce the nutrient and moisture content of the soils (Liang et al. 2016; Negasa et al. 2017a, 2017b) and thereby results in reduction of crop yield. Moreover, when Eucalyptus globulus and Eucalyptus camaldulensis trees are grown along the banks of streams and/or rivers, they decrease the volume of the water flow (Liang et al. 2016; Negasa et al. 2017b). On top of this, growing Eucalyptus globulus and Eucalyptus camaldulensis on grazing land reduces the availability and quality of forage for livestock due to soil acidification, nutrient depletion, and allelopathic effect (Liang et al. 2016). Previous studies supported the above connotation on the adverse ecological impacts of Eucalyptus globulus and Eucalyptus camaldulensis in the study site. For example, soil acidification, nutrient depletion, allelopathic effect (Bowen and Nambiar 1984; Basu and Kandasamy 1997; Hailu et al. 2003; Liang et al. 2016), and excessive water utilization (Liang et al. 2016; Negasa et al. 2017b) by Eucalyptus globulus and Eucalyptus camaldulensis are some of the

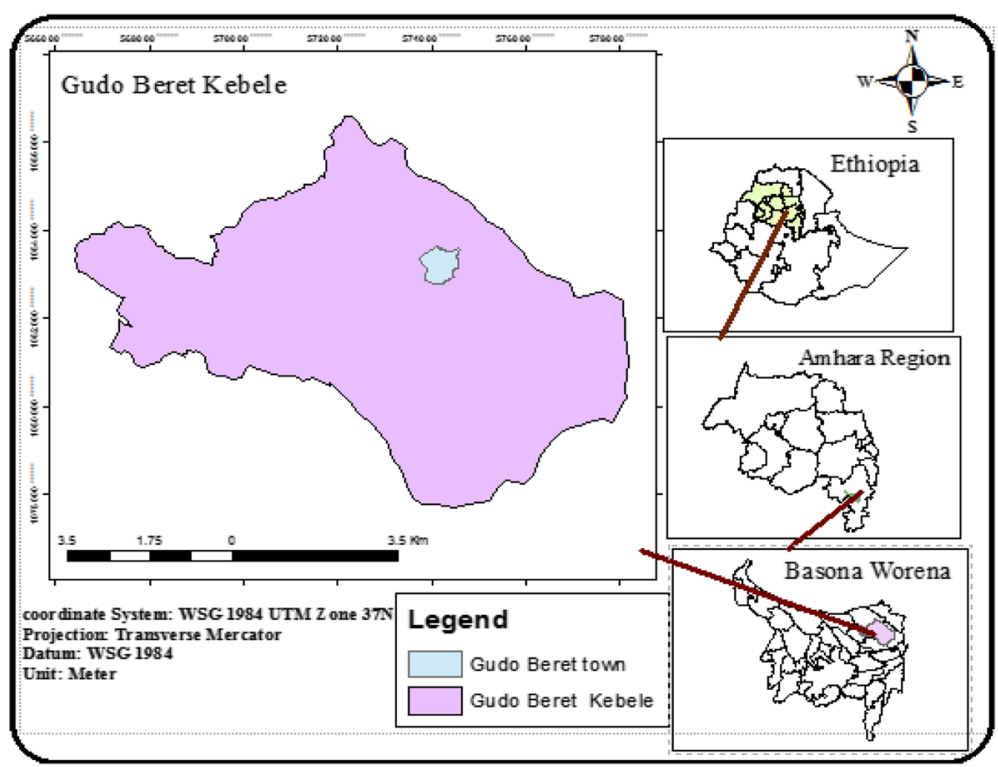

Fig. 1 Location map of the study area 
adverse ecological impacts of these species especially when they are grown on previously cultivated farmlands (Saint-André et al. 2008; Liang et al. 2016; Negasa et al. 2017b).

The soil type is predominantly a vertisol soil (Von Breitenbach 1961, 1963; Teketay and Bekele 1995; Ayele 2008). Although vertisols have better fertility when compared to other major soil types found in Ethiopia, their main constraint is water logging during the wet season and cracking in the dry season (Dubale 2001). In some parts of Gudo Beret Kebele, farmers have practiced soil burning. It is an old practice in which some researchers observed as far back as the mid-nineteenth century (McCann 1995). The main reason for the burning of soils by farmers in Basona Worena district in general and Gudo Beret Kebele, in particular, is to minimize waterlogging, control insects and weeds, and also to increase the availability of certain plant nutrients, particularly phosphorous and potassium, that improve the fertility of the soil (Dubale 2001).

\section{The questionnaire survey}

A structured questionnaire was set by administering the various socioeconomic (e.g., sex, age, income, level of education, family size, land ownership, landholding size, distance between the houses of the respondents and the nearby access road, etc.) and cognitive (e.g., knowledge, beliefs, and experience) variables (Hills 1995; Kelboro and Stellmatcher 2015; Tadesse and Kotler 2016) that would likely affect local people's knowledge on the adverse impacts and their attitudes towards growing Eucalyptus woodlot in Gudo Beret Kebele. Most socioeconomic, knowledge, and experience measuring questions were expressed in nominal scale and quantified using $2=$ yes, $1=$ unsure, and $0=$ no. Age, family size, annual income, level of education, length of residence in the area, landholding size, and distance between the houses of the respondents and the nearby access road were measured in quantitative values (Tadesse and Teketay 2017). Information on the allocation of land for Eucalyptus woodlots was measured in nominal scale and rated using $2=$ yes and $0=$ no. Question addressing local people's attitudes towards growing Eucalyptus woodlot in Gudo Beret Kebele was measured by using Likert scale and rated using $5=$ strongly agree, $4=$ agree, $3=$ unsure, $2=$ disagree, and $1=$ strongly disagree (Cohen et al. 2000; Hren et al. 2004; Tadesse and Teketay 2017). Larger values revealed positive attitudes towards growing Eucalyptus woodlot. Question addressing local people's knowledge on the adverse impacts of Eucalyptus woodlot was measured in nominal scale and rated using $2=$ yes and $0=$ no. For the supplementary open-ended questions, the respondents explained their experiences and knowledge about Eucalyptus woodlot in Gudo Beret Kebele and later used to enrich the discussion part of this article.

\section{Data collection}

We conducted a preliminary survey in order to get better information about the study site and the kind of data to be collected. To collect data, we used opinion-based questionnaire survey. The data were obtained from the household questionnaire. A structured questionnaire comprising of open- and closed-ended questions were developed and administered to acquire the data.

To collect the data in Gudo Beret Kebele, a total of 94 randomly selected households were contacted. The total sample size was determined according to Israel (1992) by using the following formula:

$$
\begin{aligned}
& n=\frac{N}{1+N(e)^{2}} \\
& n=1052 / 1+1052(0.1)^{2} \\
& n=94 \\
& \text { where } \\
& e=\text { confidence level } \\
& N=\text { total households in Gudo Beret Kebele } \\
& n=\text { sample size }
\end{aligned}
$$

The households were randomly selected through a lottery system based on their house identification numbers. The enumerators implemented the questionnaire survey via direct house-to-house visits. All the questionnaire survey was achieved by considering various socioeconomic (e.g., sex, age, income, level of education, family size, annual income, land ownership, landholding size, etc.) and cognitive (e.g., knowledge, beliefs, and experience) variables (Tadesse and Kotler 2016; Tadesse and Teketay 2017). The data were collected in May 2017.

Independent variables were derived from the following 17 questions: (i) sex, (ii) age, (iii) family size, (iv) level of education, (v) occupation, (vi) annual income, (vii) land ownership, (viii) landholding size, (ix) history of settlement, (x) length of residence in the area, (xi) source of fuelwood, (xii) woodlot ownership, (xiii) place of Eucalyptus plantation, (xiv) preference for Eucalyptus species, (xv) the difference in crop and forage production near Eucalyptus woodlot, (xvi) past knowledge about Eucalyptus woodlot, and (xvii) distance between the houses of the respondents and the nearby access road.

The dependent variables were derived from the following two questions: (i) local people's knowledge on the adverse impacts of Eucalyptus woodlot and (ii) local people's attitudes towards growing Eucalyptus woodlot.

\section{Data analyses}

Descriptive statistics, such as percentage, pie chart, means, and standard deviation, were used to analyze and 
present the data. For the binary logit and multiple linear regression analyses, we first checked whether there is singularity (i.e., when the independent variables are perfectly correlated, and one independent variable is a combination of one or more of the other independent variables) and/or multicollinearity (i.e., a condition in which the independent variables are very highly correlated (0.90 or greater)) between or among the different independent variables (Gomez and Gomez 1984; Ayele 2008; Paulson 2008; Tadesse and Kotler 2016). However, we did not find any singularity and/or multicollinearity between or among any independent variables. Moreover, we also checked the other assumptions of regression, such as linearity, homoscedasticity, heteroscedasticity, homogeneity of variance, and normality (Gomez and Gomez 1984; Ayele 2008; Paulson 2008; Tadesse and Teketay 2017). However, we did not find any problem with all the independent variables to meet the assumptions of regression. Binary logit regression model was used to analyze factors affecting local people's knowledge on the adverse impacts of Eucalyptus woodlot. The logistic distribution function was selected because it is relatively simple from the mathematical point of view and leads itself to a meaningful interpretation of the local people's knowledge on the adverse impacts of $\mathrm{Eu}$ calyptus woodlot (Gomez and Gomez 1984; Zar 1999; Paulson 2008). Moreover, multiple linear regression was used to predict local people's attitudes towards growing Eucalyptus woodlot.

For all analyses, we set the alpha value to be 0.05 . However, after accounting for multiple comparisons (17 tests per dependent variable) with a Bonferroni correction, $P \leq 0.003$ was considered significant (Gomez and Gomez 1984; Morzillo et al. 2007; Paulson 2008; Tadesse and Teketay 2017). We computed the Bonferroni correction by dividing 0.05 to 17 which is equal to 0.003 . This is because Bonferroni correction is a safeguard against multiple tests of statistical significance on the same data falsely giving the appearance of significance (Morzillo et al. 2007; Paulson 2008; Tadesse and Kotler 2016; Tadesse and Teketay 2017). All the analyses were undertaken by using SPSS version 16.

\section{Results}

A total of 94 persons responded to the questionnaire survey. Majority of the respondents (about 72\%) were males, and the average age of the respondents was about 49 years with a standard deviation of 13.44. On average, the respondents had lived in the area for about 43 years. The average family size in a household was about 5.5 persons. Regarding the level of education, majority of the respondents (about 54\%) were literate. Most of the respondents $(95 \%)$ planned to stay in the area in the future. The largest percentage (about 94\%) of the respondents had land, and the average landholding size was about 2.35 ha. Majority of the respondents (about $90 \%)$ engaged in mixed farming. The average annual income of the respondents was about 15,021.277 Ethiopian birr (which was equivalent to 643.391 USD). The average distance between the houses of the respondents and the nearby access road was about $2.96 \mathrm{~km}$ (Table 1 ).

Most of the respondents noted that they got fuelwood from Eucalyptus woodlot and natural forests (Fig. 2). Regarding the history of settlement, more than half of the respondents (about 59\%) noted that they had inherited land from their ancestors (Fig. 3).

Majority of the respondents (62\%) had Eucalyptus woodlot in Gudo Beret Kebele. For example, a considerable percentage $(30 \%)$ of the respondents used to grow Eucalyptus in their homesteads (Table 2).

Majority of the respondents (68\%) preferred to grow Eucalyptus woodlot. As a result, most of the respondents (about 92\%) noted that Eucalyptus had positive impacts. When the local people were asked about the positive impacts of Eucalyptus, what first came into their mind was

Table 1 Samples and their descriptive results

\begin{tabular}{|c|c|c|}
\hline Variable & Description & Proportion (\%) \\
\hline Total sample size $(n)$ & 94 respondents & \\
\hline \multirow[t]{2}{*}{ Sex } & Male & 74.5 \\
\hline & Female & 25.5 \\
\hline Age & $\begin{array}{l}\text { Mean }=49.05 \text { years; } \\
S D=13.87\end{array}$ & \\
\hline $\begin{array}{l}\text { Length of residence in } \\
\text { the area }\end{array}$ & $\begin{array}{l}\text { Mean }=42.85 \text { years; } \\
S D=11.36\end{array}$ & \\
\hline Family size & $\begin{array}{l}\text { Mean }=5.5 \text { persons; } \\
\mathrm{SD}=1.87\end{array}$ & \\
\hline \multirow[t]{4}{*}{ Level of education } & Illiterate & 19.1 \\
\hline & Literate & 54.3 \\
\hline & Primary & 22.3 \\
\hline & Secondary & 4.3 \\
\hline \multirow[t]{2}{*}{ Plan to stay in the area } & Yes & 94.7 \\
\hline & No & 6.3 \\
\hline \multirow[t]{2}{*}{ Land ownership } & Yes & 93.6 \\
\hline & No & 6.4 \\
\hline Landholding size & Mean $=2.35$ ha; SD $=5.23$ & \\
\hline \multirow[t]{4}{*}{ Occupation } & Crop production & 4.3 \\
\hline & Livestock & 2.1 \\
\hline & Mixed & 90.4 \\
\hline & Others & 3.2 \\
\hline Annual income & $\begin{array}{l}\text { Mean = 15,021.277 ETB; } \\
\mathrm{SD}=1143.68\end{array}$ & \\
\hline $\begin{array}{l}\text { Distance between the } \\
\text { houses of the respondents } \\
\text { and the nearby access road }\end{array}$ & $\begin{array}{l}\text { Mean }=2.96 \mathrm{~km} \\
\mathrm{SD}=3.67\end{array}$ & \\
\hline
\end{tabular}




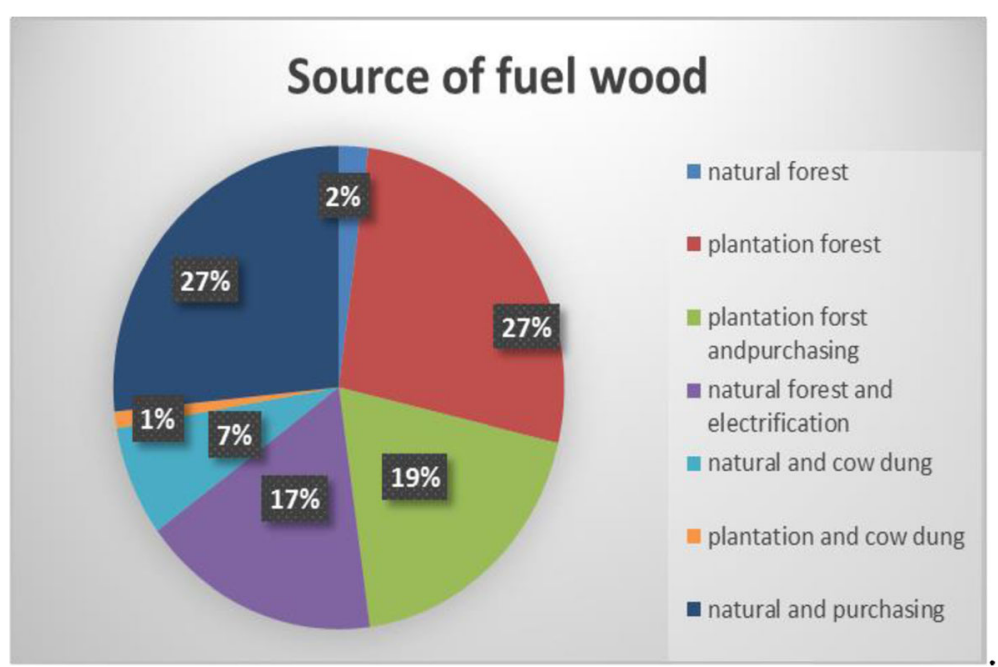

Fig. 2 Sources of fuelwood in Gudo Beret Kebele

the economic benefit that they got from Eucalyptus woodlot, for example, livelihood improvement and diversification to meet household wood demand and generating cash income through the sale of Eucalyptus wood products, such as poles, construction materials, and fuelwood. This is why most of the respondents (about 92\%) noted that Eucalyptus had positive impacts (Table 3).

In contrast, most of the respondents $(90 \%)$ noted that there was a difference in crop and forage production due to the presence of Eucalyptus woodlot in Gudo Beret Kebele (Table 3). When the respondents were asked about their knowledge on "the difference in crop and forage production due to Eucalyptus woodlot in the nearby area," they were thinking about the adverse ecological impacts of Eucalyptus, for example, reduction of crop and forage production especially when Eucalyptus is planted around farm boundaries or on grazing lands. According to the respondents, the adverse ecological impacts of Eucalyptus may include a decline in soil fertility through acidification and competition, reduction in forage availability due to allelopathic effect, and a decline in the availability of groundwater.

Majority of the respondents (71\%) noted that they had past knowledge about Eucalyptus woodlot (Table 3). Hence, the largest proportion (69\%) of the respondents had strongly agreed to have a positive attitude towards growing Eucalyptus woodlot in Gudo Beret Kebele (Table 4).

The binary logit regression model revealed that history of settlement $(\beta=0.893)$, the difference in crop and forage production near Eucalyptus woodlot $(\beta=0.895)$, and distance between the houses of the respondents and the nearby access road $(\beta=0.983)$ positively affected local

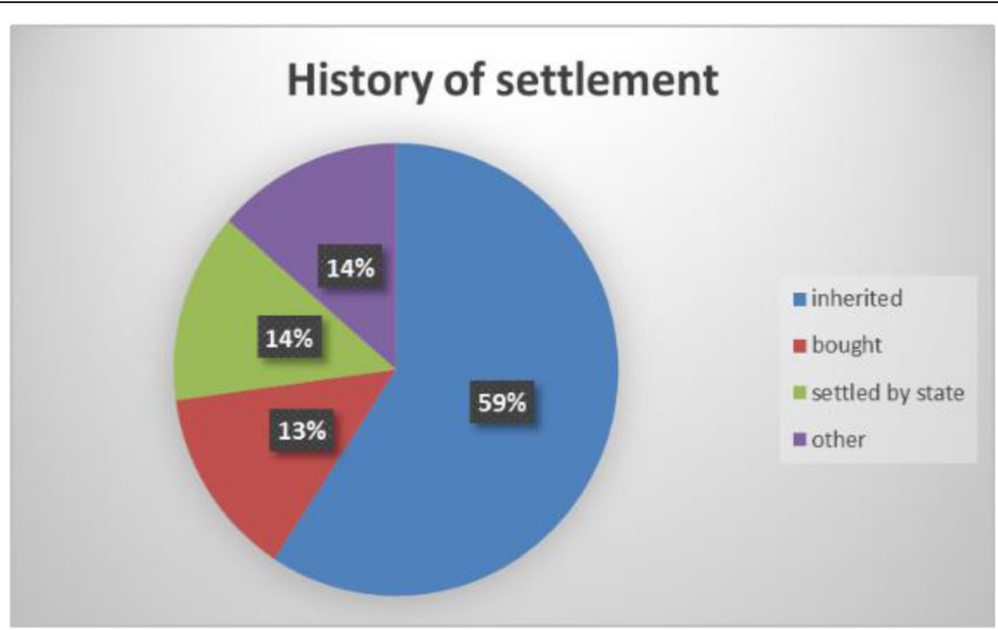

Fig. 3 History of settlement of the respondents in Gudo Beret Kebele 
Table 2 Woodlot ownership and place of Eucalyptus plantation in Gudo Beret Kebele

\begin{tabular}{lll}
\hline Variable & Description & Proportion (\%) \\
\hline Woodlot ownership & Yes & 61.7 \\
& No & 38.3 \\
Place of Eucalyptus plantation & Mountain & 20.4 \\
& Farmland boundary & 29.0 \\
& Homestead & 30.0 \\
& Miscellaneous & 20.4 \\
\hline
\end{tabular}

people's knowledge on the adverse impacts of Eucalyptus woodlot. However, level of education $(\beta=-0.834)$ and place of Eucalyptus plantation $(\beta=-1.832)$ negatively correlated with local people's knowledge on the adverse impacts of Eucalyptus woodlot. Overall, the binary logit regression model explained about $70.6 \%$ of the variance of local people's knowledge on the adverse impacts of Eucalyptus woodlot (Table 5).

The multiple linear regression model revealed that socioeconomic and cognitive variables significantly affected local people's attitudes towards growing Eucalyptus woodlot in Gudo Beret Kebele. As revealed from their coefficients, history of settlement $(\beta=0.37)$ and landholding size $(\beta=0.673)$ positively affected local people's attitudes towards growing Eucalyptus woodlot. However, the difference in crop and forage production near Eucalyptus woodlot $(\beta=-0.382)$ and distance between the houses of the respondents and the nearby access road $(\beta=-0.436)$ negatively affected local people's attitudes towards growing Eucalyptus woodlot. Overall, the multiple linear regression model revealed that socioeconomic and cognitive variables had a significant effect on local people's attitudes towards growing Eucalyptus woodlot (39.5\% variance explained) (Table 6).

Table 3 Local people's knowledge on Eucalyptus woodlot in Gudo Beret Kebele

\begin{tabular}{lll}
\hline Variable & Description & Proportion (\%) \\
\hline Do you prefer to grow Eucalyptus? & Yes & 68.1 \\
& No & 31.9 \\
Does Eucalyptus have positive impact? & Yes & 91.5 \\
& No & 8.5 \\
Does Eucalyptus have negative impacts? & Yes & 8.5 \\
& No & 91.5 \\
Was there a difference in crop and & Yes & 90.4 \\
forage production due to Eucalyptus & No & 9.6 \\
woodlot in the nearby area? & Yes & 71.3 \\
Did you have past knowledge about & No & 28.7 \\
Eucalyptus? & & \\
\hline
\end{tabular}

\section{Discussion}

This study was the first attempt that examined local people's knowledge on the adverse impacts and their attitudes towards growing Eucalyptus woodlot in Gudo Beret Kebele. Our results revealed that about $68 \%$ of the respondents preferred to grow Eucalyptus. For example, about $92 \%$ of the respondents noted that growing Eucalyptus woodlot had positive impacts on the socioeconomic situation of the community. In a recent study, Negasa et al. (2016) also noted that local people had the preference to plant more Eucalyptus in Meja watershed, central Ethiopia. This is because Eucalyptus contributes to economic benefits through the sale of wood products, such as poles, construction materials, and fuelwood (Hailu 2002; Hailu et al. 2003; Ayele 2008; Kebebew and Ayele 2010; Bekele 2015; Liang et al. 2016).

As a result, the respondents described that several households in Gudo Beret Kebele converted considerable parts of their agricultural lands to Eucalyptus woodlots. One of the possible reason could be the higher expected outputs of Eucalyptus (e.g., produce wood with good properties for the purposes of fiber, saw timber, chipboard, posts, and civil construction) with a given input and less initial investment cost (i.e., compared to crop cultivation, planting and managing Eucalyptus requires less labor, time, and capital) (Negasa et al. 2016) are attractive to households (FAO 1988, 2009; Fisseha et al. 2011; Kindu et al. 2013; Yeshaneh et al. 2013; Desalegn et al. 2014; Tesfaye et al. 2014; Bekele 2015). In addition, high market value of Eucalyptus products (e.g., Kebebew and Ayele 2010) could be another possible factor that led households to plant Eucalyptus on their farmlands in Gudo Beret Kebele. For example, previous studies noted that most households began to plant Eucalyptus woodlot around homesteads and gradually expanded to agricultural lands close to homesteads (FAO 1988, 2009; Hailu 2002; Ayele 2008; Negasa et al. 2016). Large-scale plantation of Eucalyptus, as a fastgrowing exotic, has also occurred in India, as part of a drive to reforest the sub-continent and create an adequate supply of fuel and timber for rural communities (Lal 2008). Gemechu (2010) noted that some households converted croplands that had lost crop production potentials to Eucalyptus plantations in different parts of Ethiopia where Eucalyptus could grow. A recent study conducted by Negasa et al. (2016) on the expansion of Eucalyptus in Meja Watershed, central Ethiopia, revealed that grassland and bushland decreased while Eucalyptus plantation expanded throughout the last 40 years period where the area covered by Eucalyptus plantation has increased from less than $1 \%$ in 1976 to $15.2 \%$ in 2015 across the study site. However, the expansion of monoculture Eucalyptus plantation in different parts of Ethiopia requires close follow-up and scrutiny 
Table 4 Descriptive result for item measuring local people's attitudes towards growing Eucalyptus woodlot in Gudo Beret Kebele

\begin{tabular}{lllllll}
\hline Belief statement & Strongly agree (\%) & Agree (\%) & Unsure (\%) & Disagree (\%) & Strongly disagree (\%) & M (SD) $)^{a}$ \\
\hline Agree "growing Eucalyptus woodlot" & 69.42 & 20.91 & 3.21 & 4.32 & 2.14 & $4.51(1.47)$
\end{tabular}

${ }^{a}$ Scale values (strongly agree $=5$ through strongly disagree $=1$ ) were used to calculate mean $(M)$ and standard deviation $(S D)$ values, where higher values indicate more positive attitude towards growing Eucalyptus woodlot

by considering its potential adverse ecological impacts (Liang et al. 2016).

In contrast, only about $8 \%$ of the respondents in Gudo Beret Kebele noted the negative impacts of Eucalyptus woodlot which are attributed to its effects on reduction in crop production and water use due to competition especially when grown on farmlands (Negasa et al. 2017b), soil acidification (Liang et al. 2016), nutrient depletion (Negasa et al. 2017a), allelopathic effect (Basu and Kandasamy 1997; Hailu et al. 2003), and reduction in growth potential of grass when Eucalyptus is planted near farmlands, grasslands and/or indigenous trees (Hailu et al. 2003; Saint-André et al. 2008; Negasa et al. 2017b). However, the negative impact of Eucalyptus can be minimized by practicing appropriate species and planting site selection, proper planting space, and exercising appropriate tending and harvesting operations (FAO 1988, 2009; Ayele 2008; Kebebew and Ayele 2010).

As hypothesized, the binary logit regression model revealed that history of settlement, the difference in crop and forage production near Eucalyptus woodlot, and the distance between the houses of the respondents and the nearby access road positively affected local people's knowledge on the adverse impacts of Eucalyptus woodlot (Table 5). The possible reason for the positive correlation of the history of settlement with local people's knowledge on the adverse impacts of Eucalyptus woodlot might be attributed to people with long history in the area, who are worried about their environment. In addition, when the local people know much about the difference in crop and forage production near Eucalyptus woodlot, their knowledge to notice the adverse impacts of Eucalyptus woodlot would likely increase (Hailu 2002; Negasa et al. 2016; Negasa et al. 2017b). As a result, they may likely develop good insights about the adverse impacts of Eucalyptus in the study site. Thus, history of settlement may have a positive effect on the adverse impacts of Eucalyptus in Gudo Beret Kebele. When the distance between the houses of the respondents and the nearby access road increases, people might not easily

Table 5 Factors affecting local people's knowledge on the adverse impacts of Eucalyptus woodlot in Gudo Beret Kebele

\begin{tabular}{|c|c|c|c|c|c|c|}
\hline Variable & $\beta$ & S. E & Wald & Df & $P$ value & Expected $(\beta)$ \\
\hline Constant & 1.930 & 0.435 & 0.123 & 1 & - & 1.023 \\
\hline Sex & -0.112 & 0.630 & 0.048 & 1 & 0.911 & 0.678 \\
\hline Age & 0.723 & 0.845 & 0.264 & 1 & 0.635 & 1.236 \\
\hline Level of education & -0.834 & 0.456 & 6.784 & 1 & $0.002^{a}$ & 0.925 \\
\hline Family size & -0.643 & 0.467 & 1.032 & 1 & 0.412 & 0.919 \\
\hline Occupation & 0.783 & 0.346 & 0.165 & 1 & 0.556 & -0.375 \\
\hline History of settlement & 0.893 & 0.845 & 9.689 & 1 & $0.000^{\mathrm{a}}$ & 1.823 \\
\hline Length of residence in the area & -0.296 & 0.436 & 0.134 & 1 & 0.456 & 0.732 \\
\hline Annual income & 1.523 & 0.932 & 0.083 & 1 & 0.760 & 0.362 \\
\hline Land ownership & -0.783 & 0.183 & 0.068 & 1 & 0.691 & 0.854 \\
\hline Source of fuelwood & 1.893 & 0.273 & 0.263 & 1 & 0.406 & 2.096 \\
\hline Woodlot ownership & -0.283 & 0.364 & 0.214 & 1 & 0.444 & -0.786 \\
\hline Landholding size & 0.534 & 0.945 & 0.068 & 1 & 0.834 & -0.638 \\
\hline Place of Eucalyptus plantation & -1.832 & 0.432 & 7.420 & 1 & $0.001^{\mathrm{a}}$ & -2.893 \\
\hline Preference for Eucalyptus species & -0.834 & 0.346 & 1.068 & 1 & 0.131 & -0.782 \\
\hline $\begin{array}{l}\text { The difference in crop and forage production } \\
\text { near Eucalyptus woodlot }\end{array}$ & 0.895 & 0.634 & 13.754 & 1 & $0.000^{\mathrm{a}}$ & 0.963 \\
\hline Past knowledge about Eucalyptus woodlot & 0.294 & 0.346 & 0.361 & 1 & 0.221 & 0.783 \\
\hline $\begin{array}{l}\text { Distance between the houses of the respondents } \\
\text { and the nearby access road }\end{array}$ & 0.983 & 0.576 & 8.946 & 1 & $0.001^{a}$ & 2.957 \\
\hline
\end{tabular}

Expected $(\beta)$ shows the predicted changes in the dependent variable for a unit increase in the predictor; Chi-square $\left(\chi^{2}\right)=79.0$; percentage of corrected prediction $=70.6$

${ }^{\mathrm{a}}$ Represents significance at $95 \%$ confidence level 
Table 6 Linear regression model ${ }^{a}$ to predict local people's attitudes towards growing Eucalyptus woodlot in Gudo Beret Kebele ${ }^{b}$

\begin{tabular}{|c|c|c|c|}
\hline \multirow[t]{2}{*}{ Variable } & \multicolumn{3}{|c|}{ Local people's attitudes towards growing Eucalyptus woodlot } \\
\hline & $\bar{\beta}$ & $t$ & $P$ value \\
\hline Constant & 0.365 & 0.716 & - \\
\hline Sex & 0.036 & 0.322 & 0.749 \\
\hline Age & 0.077 & 0.509 & 0.612 \\
\hline Level of education & 0.140 & 1.327 & 0.189 \\
\hline Family size & 0.031 & 0.295 & 0.769 \\
\hline Occupation & 0.128 & 1.153 & 0.252 \\
\hline History of settlement & 0.370 & $3.405^{c}$ & 0.001 \\
\hline Length of residence in the area & -0.126 & -0.767 & 0.445 \\
\hline Annual income & -0.033 & -0.337 & 0.737 \\
\hline Land ownership & -0.096 & -0.828 & 0.410 \\
\hline Landholding size & 0.673 & $3.893^{c}$ & 0.001 \\
\hline Source of fuelwood & -0.181 & -1.768 & 0.081 \\
\hline Woodlot ownership & 0.090 & 0.757 & 0.451 \\
\hline Place of Eucalyptus plantation & 0.091 & 0.876 & 0.384 \\
\hline Preference for Eucalyptus species & 0.075 & 0.688 & 0.494 \\
\hline $\begin{array}{l}\text { The difference in crop and forage production } \\
\text { near Eucalyptus woodlot }\end{array}$ & -0.382 & $-3.858^{c}$ & 0.000 \\
\hline Past knowledge about Eucalyptus woodlot & 0.001 & 0.008 & 0.993 \\
\hline $\begin{array}{l}\text { Distance between the houses of the respondents } \\
\text { and the nearby access road }\end{array}$ & -0.436 & $4.635^{c}$ & 0.001 \\
\hline
\end{tabular}

${ }^{a}$ Standardized coefficients were reported

${ }^{\mathrm{b}} \mathrm{Adj} . R^{2}=0.395, \mathrm{df}=16 ; F=3.705$, overall $P<0.002$

crepresents significance at $95 \%$ confidence level

transport the wood products (e.g., poles, construction materials, and fuelwood) of Eucalyptus so that they will be worried about the adverse impacts of Eucalyptus woodlot on their environment.

However, the binary logit regression model revealed that level of education and place of Eucalyptus plantation negatively correlated with local people's knowledge on the adverse impacts of Eucalyptus woodlot in Gudo Beret Kebele (Table 5). The possible reason could be when the level of education increases, local people might be well conscious of how to manage and control the adverse impacts of Eucalyptus woodlot. Therefore, as compared to less educated people, more educated people would likely minimize the potential negative impacts of Eucalyptus woodlot on their environment. When the knowledge of the local people about the place of Eucalyptus plantation increases, it is clear that they will be able to control and manage the adverse impacts of Eucalyptus woodlot. Previous studies noted that knowledge on forest plantation plays a key and central role in Eucalyptus plantation management and development (e.g., Hailu et al. 2003; Bernard and Jurgen 2005; Ayele 2008; Tesfaye et al. 2012; Bekele 2015; Negasa et al. 2016). Generally, the present study had generated a lot of relevant knowledge on the adverse impacts of Eucalyptus woodlot on the environment. For example, the respondents argued that the adverse impacts of Eucalyptus woodlot can be managed or controlled if appropriate silvicultural activities, such as species selection, planting space, planting site selection, pruning, thinning, and harvesting operations are put in place. Previous studies also noted that the adverse impacts of Eucalyptus can be controlled if silvicultural and plantation management techniques are properly planned and implemented (e.g., Hailu 2002; Hailu et al. 2003; Bernard and Jurgen 2005; Bekele 2015).

As predicted, the multiple linear regression model revealed that socioeconomic and cognitive variables significantly affected local people's attitudes towards growing Eucalyptus woodlot in Gudo Beret Kebele. For example, history of settlement was positively correlated with local people's attitudes towards growing Eucalyptus woodlot (Table 6). One of the possible reasons could be people with ample information on the history of their settlement in the area might be more interested to plant and grow Eucalyptus woodlot. As a result, they may develop positive attitudes towards growing Eucalyptus woodlot because they may expect high economic returns derived from Eucalyptus including financial profits obtained from the sale of poles, construction materials, and fuelwood (Hailu 2002; Hailu et al. 2003; 
Bernard and Jurgen 2005; Kebebew and Ayele 2010; Bekele 2015; Liang et al. 2016; Negasa et al. 2016). Moreover, the live Eucalyptus tree can serve as a fence and also Eucalyptus grown around farmlands can serve as a windbreak (Hailu 2002; Lal 2008; Zewdie 2008). The other fact is that economic poverty is one of the rampant problems in the study site (Ayele 2008). Although the respondents know much about the adverse impacts of Eucalyptus resulted from their long history of settlement in the study site, they may develop positive attitudes towards growing Eucalyptus woodlot because they expect that growing Eucalyptus woodlot contributes much to improve and diversify their livelihood and cash income through the sale of Eucalyptus wood products (e.g., Hailu 2002; Bernard and Jurgen 2005; Ayele 2008; Lal 2008; Gemechu 2010; Kebebew and Ayele 2010; Bekele 2015; Negasa et al. 2016).

The result further revealed that landholding size was positively correlated with local people's attitudes towards growing Eucalyptus woodlot (Table 6). It is intuitively logical that people who have large land size may be more interested to plant and grow Eucalyptus woodlot so that their attitudes towards growing Eucalyptus woodlot might increase as far as they have enough landholdings. Similarly, previous studies noted that local people's attitudes towards growing and managing forests in particular and conserving and managing natural resources in general were positively affected by socioeconomic variables, such as history of their settlement in the area and land ownership (e. g., Mehta and Kellert 1998; Mehta and Heinen 2001; Husain and Bhattacharya 2004; Kideghesho et al. 2007; Lee et al. 2009; Tesfaye et al. 2012; Takahashi and Todo 2012; Tadesse and Kotler 2016).

However, the difference in crop and forage production near Eucalyptus woodlot and distance between the houses of the respondents and the nearby access road were negatively related with local people's attitudes towards growing Eucalyptus woodlot in Gudo Beret Kebele (Table 6). Previous studies also revealed that local people's attitudes towards growing and managing forests were negatively influenced by the distance between the houses of the respondents and the nearby access road (e.g., Mehta and Kellert 1998; Mehta and Heinen 2001; Tesfaye et al. 2012). The negative attitudes of the local people towards Eucalyptus woodlot may be connected with its adverse effects on the various properties of the soil (e.g., chemical and biological) and high potential of water and nutrient competition. For example, previous studies noted that when Eucalyptus tree species are planted around farmlands, in addition to competing for nutrients and water (Liang et al. 2016; Negasa et al. 2017a, 2017b), the roots of Eucalyptus trees make tillage practice difficult (Hailu 2002; Hailu et al. 2003). The other adverse effect of Eucalyptus is supposed to be making palatable forage unavailable to livestock especially when grown on grasslands (e.g., due to allelopathic effect) (Basu and Kandasamy 1997; Liang et al. 2016; Negasa et al. 2017b). Moreover, the adverse impacts of Eucalyptus can also be attributed by the trees' unique characteristics, such as absorption of high amounts of nutrient and water through its massive root system (e.g., Hailu et al. 2003; Liang et al. 2016; Negasa et al. 2017a, 2017b), shading effects, and dead leaves may also contain toxic substances that hinder the growth of food crops, grass, and indigenous trees, perhaps due to its allelopathic nature (Basu and Kandasamy 1997; Hailu 2002; Hailu et al. 2003; Liang et al. 2016). When the distance between the houses of the respondents and the nearby access road decreases, people may easily transport the wood products of Eucalyptus including poles, construction materials, and fuelwood to the market area (Bernard and Jurgen 2005; Lal 2008; Kebebew and Ayele 2010). Hence, their attitudes towards growing Eucalyptus woodlot would likely increase.

\section{Conclusions}

The decline in wood resource, growing demand for wood products, and its high income contributions are encouraging the rapid expansion of Eucalyptus woodlots by the rural households in Ethiopia (FAO 1988, 2009; Hailu 2002; Ayele 2008; Gemechu 2010; Negasa et al. 2016) including North Shoa Administrative Zone in Amhara Region. Our study also revealed that some households allocated large portion of their farmlands to Eucalyptus woodlots as compared to other land use type in Gudo Beret Kebele. This is because Eucalyptus is economically the most important tree species established as woodlot by the rural households (e.g., Hailu 2002; Ayele 2008; Gemechu 2010; Kebebew and Ayele 2010; Bekele 2015; Negasa et al. 2016; Negasa et al. 2017a). Rural households also considered Eucalyptus woodlot as a form of financial security against any sort of unforeseen financial problems (Kebebew and Ayele 2010; Negasa et al. 2016). For example, the increased land allocation for the production of Eucalyptus is one of the indicators for the booming importance of Eucalyptus for rural households' livelihood diversification and improvement (Hailu 2002; Ayele 2008; Zewdie 2008; Bekele 2015; Liang et al. 2016; Negasa et al. 2016). Moreover, the adoption of the growing practice of Eucalyptus woodlot by the local people in Gudo Beret Kebele might also be attributed to the value of Eucalyptus for poles, construction material, fuelwood, and shelterbelt against wind erosion.

Our study revealed that local people's knowledge on the adverse impacts of Eucalyptus woodlot was positively correlated with the history of settlement, the difference in crop and forage production near Eucalyptus woodlot, 
and the distance between the houses of the respondents and the nearby access road, but it was negatively correlated with the level of education and place of Eucalyptus plantation. Moreover, local people's attitudes to allocate land and grow Eucalyptus woodlot was positively correlated with the history of settlement and landholding size, but it was negatively correlated with the difference in crop and forage production near Eucalyptus woodlot and distance between the houses of the respondents and the nearby access road. From this, it is possible to conclude that household socioeconomic characteristics and institutional factors can enhance or hinder the decision of rural households' to grow Eucalyptus woodlot. As long as growing Eucalyptus is a potential source of financial income and contributes highly to the livelihood diversification and improvement to the farming households (e.g., Ayele 2008; Kebebew and Ayele 2010; Bekele 2015), restricting and/or hindering the growing of Eucalyptus without considering the existing benefit should not be contemplated. Even though Eucalyptus woodlot has positive impacts on socioeconomic conditions, on the other hand, it has its own adverse impacts on the environment, such as reduction in crop productivity and growth potential of grass when it is planted near farmlands, grasslands, and/or indigenous trees (Negasa et al. 2017b), for example, due to the absorption of high amounts of nutrient and water through its massive root system (Bowen and Nambiar 1984; Hailu et al. 2003; Liang et al. 2016; Negasa et al. 2017a), shading effects, and due to its allelopathic nature (Gosh et al. 1978; Basu and Kandasamy 1997; Saint-André et al. 2008; Liang et al. 2016). However, the adverse impacts of Eucalyptus can be controlled by implementing appropriate planting space, species and planting site selection, and also by practicing proper silvicultural and harvesting techniques (Hailu et al. 2003; Kebebew and Ayele 2010; Bekele 2015).

\section{Recommendations}

Based on the findings of the present study, we would like to recommend the following:

- Creating awareness and promoting extension education to farmers and other stakeholders about the selection of the best adapted phenotype and genotype for Eucalyptus woodlot, site selection, planting space as well as tending and harvesting techniques are crucial to control the adverse impacts of Eucalyptus on the natural environment.

- Because of fast human population growth in the study area and close association with primary resources exploited from ecosystems (e.g., food crops, fodder, fuel, timber for building and income generation, water, soil nutrients, wildlife, and indigenous biodiversity), the long-term future of this study area depends on the development of policies and strategies which promote the ability for communities to contribute to, and benefit from their conservation. Thus, comprehensive future research is crucial to explore in more detail this vital part of the long-term perspective on ecosystem response to climate change and human interaction.

- Native forest (i.e., composed of indigenous woody species) or even secondary regrowth native species should not be cleared to make way for Eucalyptus plantation and its expansion.

- If possible, Eucalyptus could be tried in mixed species system, using indigenous tree species and vegetation to minimize the adverse impacts of Eucalyptus on the natural environment.

- Sustainable solutions to environment and development problems that consider broader social, political, economic, and environmental contexts and the ethical implications of their application by applying knowledge, theories, and approaches from ecology, economics, and policy studies are essential to minimize the adverse impacts of Eucalyptus in the study site and elsewhere.

- Forestry extension agents should treat farmers as people with valuable information and knowledge about Eucalyptus since they are vital for providing insights on how the needs of the people can be met, which includes maintaining sound environmental conditions through minimizing the adverse impacts of Eucalyptus.

- Women should be involved in Eucalyptus tree planting and management programmes as decisionmakers and implementers since fuelwood collection and consumption is their own responsibility, and they also remain in the villages all year round.

- The main source of energy for the local people in Gudo Beret Kebele is derived from biomass (e.g., fuelwood, crop residues, and cow dungs). Thus, dissemination of energy-efficient technologies (e.g., energy-saving stoves), creating job opportunities, family planning, strict government energy policy, and provision of alternative energy (i.e., other than biomass energy) from the government with less taxation may decrease the bad consequences. Solutions to alleviate the unsustainable use of biomass energy, in turn, reduce environmental degradation in the study site and elsewhere in Ethiopia. For example, other sources of energy such as hydropower, wind power, solar energy, and natural gas can potentially offer Ethiopia major economic development opportunity, thereby, reducing poverty and environmental degradation. 
- Foresters, natural resource experts and managers, environmentalists, land use planners, and policymakers should take the right and careful decision by assessing the overall socioeconomic and ecological aspects of Eucalyptus woodlot based on the interests of various stakeholders including local communities.

- The data for the questionnaire were collected from a cross-sectional survey of a single year. This suggests that the data do not capture possible changes over time periods in household demographics and resource endowments that might occur during the different years. Cognitive variables, such as knowledge, experience, beliefs, and values that would affect local people's attitudes towards growing Eucalyptus woodlots in Gudo Beret Kebele, may change over time. Moreover, local people's knowledge on the adverse impacts of Eucalyptus woodlot may change over time. Therefore, future research is crucial to consider the time dimension as another possible and influential factor while studying local people's knowledge on the adverse impacts and their attitudes towards growing Eucalyptus woodlot in Gudo Beret Kebele and elsewhere.

\begin{abstract}
Acknowledgements
The authors would like to thank the Research and Community Service Office at Debre Berhan University for supporting this research financially. Our appreciation also goes to the following institutions: Agriculture and Natural Resources Development Office in Basona Worena district and Gudo Beret Kebele Administration Office for their unreserved cooperation in issuing the permit to work in the study area. Authors would like to thank the local people residing in Gudo Beret Kebele for sharing their fruitful ideas and abundant experiences about Eucalyptus woodlot grown in the area and its contribution to socioeconomic development during the questionnaire survey. More importantly, authors are thankful to the leaders of Gudo Beret Kebele who coordinated and encouraged the local people to willingly involve themselves and participate in the valuable questionnaire survey. The data enumerators who helped in handling the questionnaire survey via house-to-house visits were greatly acknowledged. The authors would like to thank the editor-in-chief of Ecological Processes and the three anonymous reviewers for their valuable comments, critics, and suggestions that helped much to improve the earlier version of the manuscript.
\end{abstract}

\section{Funding}

The authors would like to forward their gratitude to Debre Berhan University for covering all sources of the research funding that helped in the design of the study and collection, analyses, and interpretation of the data and also in writing of the manuscript.

\section{Authors' contributions}

SAT designed and conducted the field research, analyzed the data, and drafted the manuscript. SMT interpreted the results and helped in the manuscript writing. Both authors read, revised, and approved the final version of the manuscript.

\section{Competing interests}

The authors declare that they have no competing interests.

\section{Publisher's Note}

Springer Nature remains neutral with regard to jurisdictional claims in published maps and institutional affiliations.

\section{Author details}

'Department of Natural Resources Management, College of Agriculture and Natural Resource Sciences, Debre Berhan University, P.O. Box 445, Debre Berhan, Ethiopia. ${ }^{2}$ Department of Forestry, College of Agriculture, Wollo University, P.O. Box 1145, Dessie, Ethiopia.

Received: 24 August 2017 Accepted: 9 October 2017

Published online: 31 October 2017

\section{References}

Ayele ZE (2008) Smallholder farmers' decision making in farm tree growing in the highlands of Ethiopia. PhD Dissertation. Oregon State University, USA, p 158

Basu PK, Kandasamy A (1997) Effect of Eucalyptus monoculture on the soils of southwest Bengal, Midnapore district. J Trop For 19:33-45

Bekele T (2015) Integrated utilization of Eucalyptus globulus grown on the Ethiopian highlands and its contribution to rural livelihood: a case study of Oromia, Amhara and Southern Nations Nationalities and People's Regional State, Ethiopia. Int J Basic Appl Sci 4:80-87

Bernard N, Jurgen P (2005) The contribution of smallholder forest plantation development to the livelihood farm households in the high forest zone of Ghana. University of Deresden, Germany

Bowen GD, Nambiar EKS (1984) Nutrition of plantation forests. Academic Press, London, pp 53-78

Cohen L, Manion L, Morrison K (2000) Research methods in education, 5th edn Routledge Falmer, UK, London

Desalegn T, Cruzd F, Kindu M, Turrióna MB, Gonzalo J (2014) Land-use/land-cover (LULC) change and socioeconomic conditions of local community in the central highlands of Ethiopia. Int J Sustain Dev World Ecol 21(5):406-413

Dubale P (2001) Soil and water resources and degradation factors affecting productivity in Ethiopian highland agro-ecosystems. Northeast Afr Stud 8:27-52

Ethiopian Forestry Action Program (EFAP) (1994) Final report. Vol. 3-issues and actions. EFAP Secretariat, Addis Ababa

FAO (1988) The Eucalyptus dilemma. Food and Agriculture Organization of the United Nations, Rome, p 39

FAO (2009) Eucalyptus in east Africa: the socioeconomic and environmental issues. FAO Sub-regional Office Eastern Africa, Addis Ababa, p 40

Fisseha G, Gebrekidan H, Kibret K, Yitaferu B, Bedadi B (2011) Analysis of land use/land cover changes in the Debre-Mewi watershed at the upper catchment of the Blue Nile Basin, northwest Ethiopia. J Biodivers Environ Sci 1(6):184-198

Gemechu T (2010) Expansion of Eucalyptus plantations by smallholder farmers amid natural forest depletion: case study from Mulo district in central Oromia. In: Luis G, Wubalem T, Eduardo T, Rosana R (eds) Eucalyptus species management, history status and trends in Ethiopia, pp 335-350

Gomez KA, Gomez AA (1984) Statistical procedures for agricultural research, 2nd edn. Wiley, New York, p 680

Gosh RC, Kaul ON, Rao BKS (1978) Some aspects of water relations and nutrients in Eucalyptus plantations. Indian Forester 104:517-524

Hailu Z (2002) Ecological impact evaluation of Eucalyptus plantations in comparison with agricultural and grazing land-use types in the highlands of Ethiopia. Doctoral thesis. Institute of Forest Ecology, University of Natural Resources and Life Sciences, Vienna, p 283

Hailu Z, Sieghardt M, Schume H, Ottner F, Glatzel G, Assefa B, Hailu TT (2003) Impact of Eucalyptus globulus and Eucalyptus camaldulensis small scale plantations on chemical and physical soil properties and on soil hydrological parameter in the highland of Ethiopia-a comparison with other land-use systems. Final Project-Report, p 178

Hall N, Johnston RD, Chippendale GM (1970) Forest trees of Australia. Australian Government Publishing Service, Canberra

Hills AM (1995) Empathy and belief in the mental experience of animals. Reviews and research reports. Anthrozoös 8:132-142

Hren D, Lukic IK, Marusic A, Vodopivec I, Vujaklija A, Hrabak M, Marusic M (2004) Teaching research methodology in medical schools: students' attitudes towards and knowledge about science. Med Educ 38:81-86

Husain Z, Bhattacharya RM (2004) Attitudes and institutions: contrasting experience of joint forest management in India. J Environ Dev Econ 9:563-577

Israel GD (1992) Sampling the evidence of extension program impact. Program evaluation and organizational development, ISAF, University of Florida

Jacobs MR (1955) Growth habits of the eucalypts. Forestry and Timber Bureau, Canberra, p 262 
Jacobs MR (1961) Eucalyptus as an exotic. In: The report and documents of the Second World Eucalyptus Conference August 1961, Brazil. Forestry and Timber Bureau, Canberra

Kebebew Z, Ayele G (2010) Profitability and household income contribution of growing Eucalyptus globulus (Labill.) to smallholder farmers: the case of central highland of Oromia, Ethiopia. Eur J Appl Sc 2:25-29

Kelboro G, Stellmatcher T (2015) Protected areas as contested spaces: Nech Sar National Park, Ethiopia, between 'local people', the state and NGO engagement. Environ Dev 16:63-75

Kideghesho J, Roskaft RE, Kaltenbornb P (2007) Factors influencing conservation - attitudes of local people in Western Serengeti, Tanzania. Int J Biodivers Conserv 16:2213-2230

Kindu M, Glatzel G, Tadesse Y, Yosef A (2006) Tree species screened on nitosols of central Ethiopia: biomass production, nutrient contents and effect on soil nitrogen. J Trop For Sci 18:173-180

Kindu M, Schneider T, Teketay D, Knoke T (2013) Land use/land cover change analysis using object-based classification approach in Munessa-Shashemene landscape of the Ethiopian highlands. Remote Sens 5:2411-2435

Knight SE, Vrij A, Cherryman J, Nunkoosing K (2004) Attitudes towards animal use and animal mind. Anthrozoös 17:43-62

Lal P (2008) Clonal Eucalyptus plantations in India. Ind Forester 134:1561-1570

Lee TM, Sodhi NS, Prawiradilaga DM (2009) Determinants of local people attitudes towards conservation and the consequential effects on illegal resource harvesting in the protected area of Sulawesi (Indonesia). J Environ Conserv 36:157-170

Liang J, Reynolds T, Wassie A, Collins C, Wubalem A (2016) Effects of exotic Eucalyptus spp. plantations on soil properties in and around sacred natural sites in the northern Ethiopian highlands. AIMS Agric Food 1:175-193

McCann JC (1995) People of the plow: an agricultural history of Ethiopia 18001990. University of Wisconsin Press, Madison, p 298

Mehta JN, Heinen JT (2001) Does community-based conservation shape favorable attitudes among locals? An empirical study from Nepal. Environ Manag 28:165-177

Mehta JN, Kellert SR (1998) Local people attitudes towards community-based conservation policy and programmes in Nepal: a case study in the MakaluBarun conservation area. Environ Conserv 36:320-333

Morzillo AT, Mertig AG, Garner N, Liu J (2007) Resident attitudes towards black bears and population recovery in east Texas. Hum Dimens Wildl 12:417-428

Negasa DJ, Mbilinyi BP, Mahoo HF, Lemenih M (2016) Evaluation of land use/land cover changes and Eucalyptus expansion in Meja watershed, Ethiopia. J Geogr Environ Earth Sci Int 7(3):1-12

Negasa DJ, Mbilinyi BP, Mahoo HF, Lemenih M (2017a) Comparative assessment of soil and nutrient losses from three land uses in the central highlands of Ethiopia. Int J Water Resour Environ Eng 9:1-7

Negasa DJ, Mbilinyi BP, Mahoo HF, Lemenih M (2017b) Effect of Eucalyptus expansion on surface runoff in the central highlands of Ethiopia. Ecol Process 6(1):1-8

Paulson DS (2008) Biostatistics and microbiology: a survival manual. BioScience Laboratories, Inc., Bozeman

Saint-André L, Laclau JP, Deleporte P, Gava JL, Gonçalves JLM, Mendham D, Nzila JD, Smith C, Toit BD, Xu DP, Sankaran KV, Marien JN, Nouvellon Y, Bouillet JP, Ranger J (2008) Slash and litter management effects on Eucalyptus productivity: a synthesis using a growth and yield modelling approach. Site management and productivity in tropical plantation forests, p 173

Tadesse SA, Kotler BP (2016) Attitudes of local people towards the mountain nyala (Tragelaphus buxtoni) in Munessa, Ethiopia. Afr J Ecol 54:488-499

Tadesse SA, Teketay D (2017) Perceptions and attitudes of local people towards participatory forest management in Tarmaber district of North Shewa Administrative Zone, Ethiopia: the case of Wof-Washa forest. Ecol Process 6(17):1-16

Takahashi R, Todo Y (2012) Impact of community-based forest management on forest protection: evidence from an aid-funded project in Ethiopia. Environ Manag 50:396-404

Teketay D, Bekele T (1995) Floristic composition of Wof-Washa natural forest, central Ethiopia: implications for the conservation of biodiversity. Feddes Repertorium 106:127-147

Tesfaye S, Guyassa E, Raj AJ, Birhane E, Wondim GT (2014) Land use and land cover change, and woody vegetation diversity in human driven landscape of Gilgel Tekeze Catchment, Northern Ethiopia. Int J Forestry Res 2014:1-10

Tesfaye Y, Anders R, Folke B (2012) Attitudes of local people towards collective action for forest management: the case of PFM in Dodola area in the Bale Mountains, southern Ethiopia. Int J Biodivers Conserv 21:245-265
Von Breitenbach F (1961) Forests and woodlands of Ethiopia-a geobotanical contribution to the nowledge of the principal plant communities of Ethiopia, with special regard to forestry. Ethiop Forestry Rev 1:5-16

Von Breitenbach F (1963) The indigenous trees of Ethiopia. Ethiopian Forestry Association, Addis Ababa

Yeshaneh E, Wagner W, Exner-Kittridge M, Legesse D, Blösch G (2013) Identifying land use/cover dynamics in the Koga Catchment, Ethiopia, from multi-scale data, and implications for environmental change. Int J Geo-Inf 2:302-323

Zar JH (1999) Biostatistical analysis, 4th edn. Prentice-Hall, London

Zewdie M (2008) Temporal changes of biomass production, soil properties and ground flora in Eucalyptus globulus plantations in the central highlands of Ethiopia. Doctoral dissertation. Swedish University of Agricultural Sciences, Uppsala, p 74 Accessed on 21 June 2017

\section{Submit your manuscript to a SpringerOpen ${ }^{\mathcal{O}}$ journal and benefit from:}

- Convenient online submission

- Rigorous peer review

- Open access: articles freely available online

- High visibility within the field

- Retaining the copyright to your article

Submit your next manuscript at $>$ springeropen.com 